\title{
Role of Drainage of Preperitoneal Space in Postoperative Wound Sepsis
}

\author{
Emad K. Bayumi ${ }^{1}$, Aly Saber ${ }^{2}$ \\ ${ }^{1}$ Crimean Medical Academy Named After S.I. Georgiesky of Crimea Federal University, Crimea, Russia \\ ${ }^{2}$ Port-Fouad General Hospital, Port-Fouad, Egypt
}

Email address:

Emadsurg666@hotmail.com (E. K. Bayumi), Alysaber54@gmail.com (A. Saber)

\section{To cite this article:}

Emad K. Bayumi, Aly Saber. Role of Drainage of Preperitoneal Space in Postoperative Wound Sepsis. Journal of Surgery. Special Issue: Abdominal Surgery: Toward the Best. Vol. 4, No. 1-1, 2015, pp. 11-15. doi: 10.11648/j.js.s.2016040101.13

\begin{abstract}
Introduction: The incidence of surgical site infection increases with the degree of abdominal contamination. Previous studied claimed the effectiveness of putting a negative suction drain in the subcutaneous space in prevention of wound infection and wound dehiscence in patients of peritonitis. Aim was to study the effect of drainage of preperitoneal space in postoperative wound infection. Patients and Methods: A total of 200 patients with secondary peritonitis due to perforated appendicitis, perforated duodenal ulcers and traumatic bowel injuries were divided into main two groups; group A; wound closure with preperitoneal submuscular suction drainage and group B; wound closure without drain. End Points: The end points of the study were wound infection and time off from work. Results: The overall rates of wound infection in were $19 \%$ and $24 \%$ in group A and B respectively. Therefore the mean total hospital stay in both groups was $8.48 \pm 3$ and $14.76 \pm 4.41$ days respectively. In the other hand, the mean time to return work after being discharged from the hospital was $8.5 \pm 1.13$ in group A and $8.59 \pm 1.1$ in of group B. The mean time off from work was $16.98 \pm 4.13$ days in group A and $23.38 \pm 5.51$ days in group B. Conclusion: Incidence of surgical site infection is high in case of complicated appendicitis and has its direct effect on the extent of hospital stay and time off from work and those with drainage of preperitoneal space showed more time of hospital stay and more time off from work.
\end{abstract}

Keywords: Preperitoneal Space, Drainage, Wound Sepsis

\section{Introduction}

Peritonitis is classified into primary, secondary and tertiary peritonitis. Secondary and tertiary peritonitis are associated with higher morbidity with mortality rates[1]. The procedure used to treat the infection depends on the anatomical site of infection, the degree of peritoneal inflammation, the generalized septic response, the patient's underlying condition, and the available resources of the treatment center [2]. Post-operative peritonitis can be a life-threatening complication of abdominal surgery associated with high rates of organ failure and mortality $[3,4]$. The incidence of surgical site infection (SSI) increases with the degree of contamination. SSI may be expected if the wound is closed in the setting of gross abdominal contamination. The employment of perioperative, systemic antibiotics; wound-protector devices; and lavage of the wound at the end of therapy do not reliably prevent this complication. These wounds should be left open and should be treated with wet-to-dry dressing changes several times a day, or VAC dressing should be applied [5,6 ]. Likewise drainage following appendicectomy is usually determined by whether the underlying appendicitis is simple/complicated and largely determined by the surgeons' belief $[7,8]$. Previous studied claimed the effectiveness of putting a negative suction drain in the subcutaneous space in prevention of wound infection and wound dehiscence in patients of peritonitis $[9,10]$.

Preperitoneal space is the space between the peritoneum and transversalis fascia. Bogros (1786-1825) described a triangular space in the iliac region between the iliac fascia, transversalis fascia, and parietal peritoneum. In the modern concept, this space lies between the peritoneum and posterior lamina of the transversalis fascia. In 1858, Retzius described the homonymous space, situated anterior and lateral to the urinary bladder (prevesical space). In 1975, Fowler reported that the preperitoneal fascia of the groin is distinct from the transversalis fascia [11]. Aim was to study the effect of drainage of preperitoneal space in postoperative wound 
infection.

\section{Patients and Methods}

A total of 200 patients with secondary peritonitis due to perforated appendicitis, perforated duodenal ulcers and traumatic bowel injuries were divided into main two groups; group $\mathrm{A}$; wound closure with preperitoneal submuscular suction drainage and group B; wound closure without drain.

\subsection{Surgical Teams \& Study Sites}

Operations were performed in department of general and gastroenterology surgery, Crimean medical academy named after S.I. Georgievsky, Crimean federal university named after V.I. Vernadsk, Russia and in Port-Fouad general hospital, Port-Fouad, Port-Said, Egypt .

\subsection{Randomization}

Randomization was performed prior to study commencement as follows: Opaque envelopes were numbered sequentially from 1 to 200 . A computer-generated table of random numbers was used for group assignment; if the last digit of the random number was from 0 to 4 , assignment was to Group A \{wound closure with preperitoneal submuscular suction drainage $\}$, and if the last digit was from 5 to 9 , assignment was to Group $\mathrm{B}$ \{wound closure without drain $\}$.The assignments were then placed into the opaque envelopes and the envelopes sealed. As eligible participants were entered into the trial, these envelopes were opened in sequential order to give each patient his or her random group assignment. The envelopes were opened by the operating surgeon after patient consent and just prior to surgery.

\subsection{Ethical Consideration}

Written consents were obtained from all patients before the study. The steps of both operative interferences were explained to all patients. The local ethics committee had approved all operative procedures. Ethical approval for this study was granted by the ethical review committee under supervision of department of general and gastroenterology surgery, Crimean medical academy named after S.I. Georgievsky, Crimean federal university named after V.I. Vernadsk, Russia

\subsection{Operative Technique}

Complicated appendicitis was observed in all patients and confirmed by gross examination of the surgical team as well as pathological study. \{Figure1\}

Group A : wound closure with preperitoneal submuscular suction drainage:

After completion of the operative steps for the primary cause, the preperitoneal space was drained using suction drain of 20 French gouges. \{Figure2\}

Group B: Wound closure without drain:

After completion of the operative steps for the primary cause, the wound was closed without insertion of drain in the preperitoneal space. $\{$ Figure 3$\}$

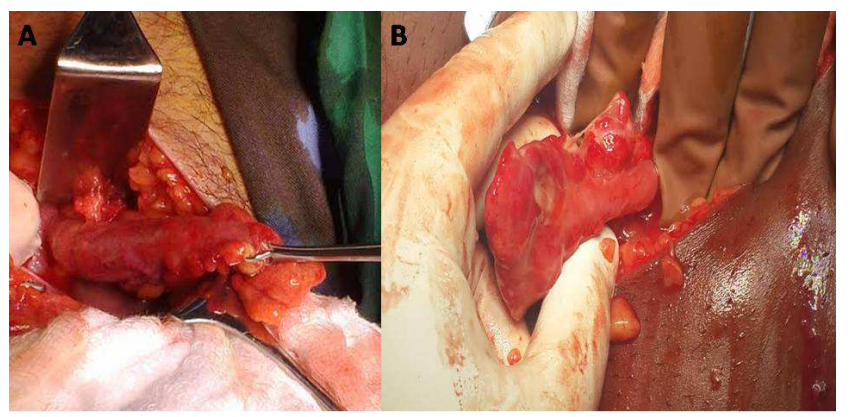

Figure 1. An operative photograph showing grossly inflamed appendix with evidence of localized peritonitis [A] and perforated appendicitis at the base [B].

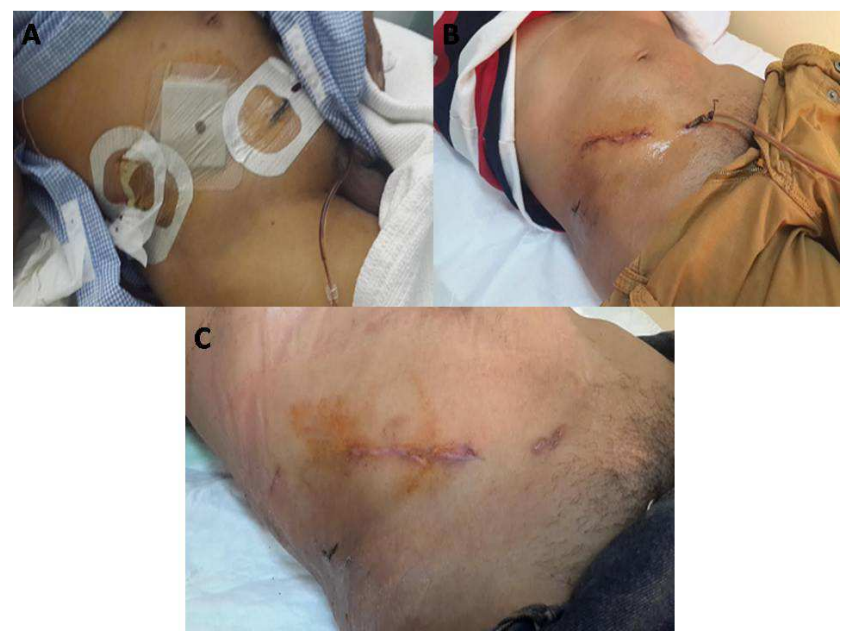

Figure 2. A postoperative photograph showing drain in position $[A, B]$ and the site of drain after being removed [C].

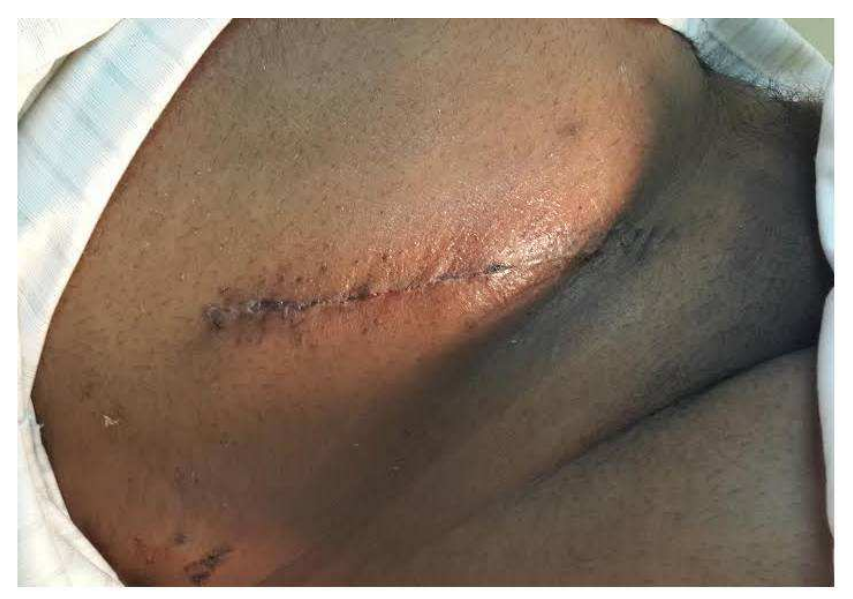

Figure 3. A postoperative photograph showing healed wound without drain.

\subsection{End Points}

The end points of the study were wound infection and time off from work. Postoperative wound infection is classified as superficial involving skin and subcutaneous tissues, deep involving deeper tissues down to the preperitoneal plane and the intraperitoneal infection involving organs and any 
peritoneal compartment [12]. Time off from work is defined as the number of days between the day of surgery and the first day a patient returned to work [13].

\subsection{Statistical Analysis}

The statistical tests were run on a compatible personal computer using the Statistical Package for Social Scientists (SPSS) for windows15. The values were expressed as means \pm standard errors of deviation. The mean values of the groups were compared by one-way analysis of variance (ANOVA) and paired comparisons of the groups were done using the paired student $t$ test. $\mathrm{P}<0.05$ was considered significant.

\section{Results}

There was no statistical difference between both groups regarding their demographic data such as age, sex, special habits and body mass index [BMI] as shown in table1.

Table 1. Showing subdivision of both groups regarding age and body mass index.

\begin{tabular}{lllll}
\hline & & GroupA & GroupB & Pvalue \\
\hline \multirow{2}{*}{ Age } & Age $<30\{15-----29\}$ & $\mathrm{N}=68$ & $\mathrm{~N}=66$ & \\
& Age $>30\{30-----48\}$ & $\mathrm{N}=32$ & $\mathrm{~N}=34$ & \\
Sex & Male & $\mathrm{N}=58$ & $\mathrm{~N}=53$ & \\
& Female & $\mathrm{N}=42$ & $\mathrm{~N}=47$ & $P \geq 0.05$ \\
& $\mathrm{BMI}<25\{22---24.9\}$ & $\mathrm{N}=26$ & $\mathrm{~N}=22$ & \\
BMI & $\mathrm{BMI}<30\{25---29.9\}$ & $\mathrm{N}=64$ & $\mathrm{~N}=54$ & \\
& $\mathrm{BMI}>30\{30---34.9\}$ & $\mathrm{N}=10$ & $\mathrm{~N}=24$ & \\
\hline
\end{tabular}

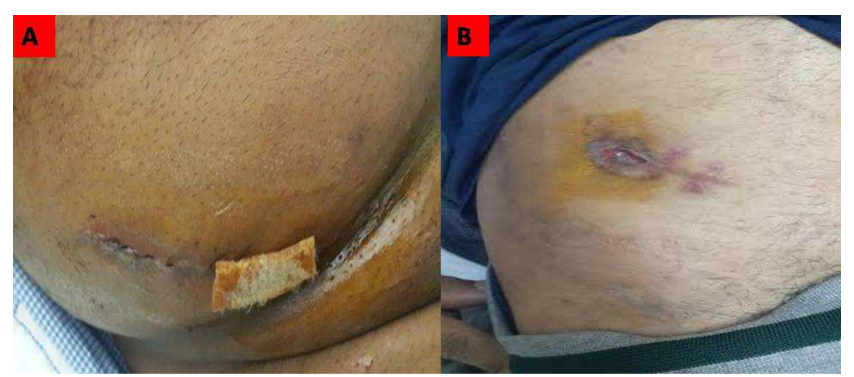

Figure 4. A postoperative photograph showing wound infection and aedema of the surrounding skin [A] and open wound drainage [B].

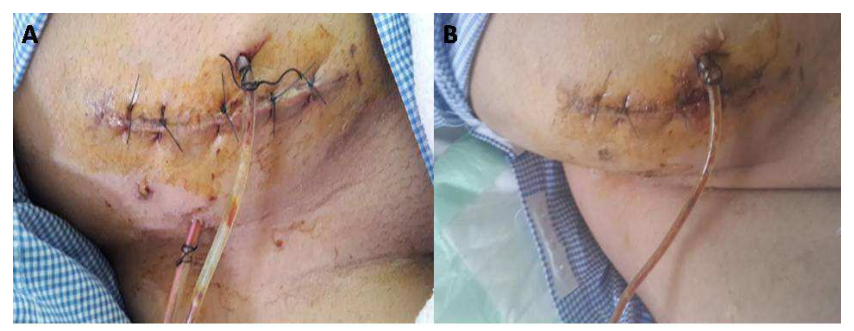

Figure 5. A postoperative photograph showing superficial wound infection in group A patients with drain in position $[A, B]$.

The mean operative time in both groups was the same 62.9 \pm 11 .1; ranging from $45-80$ minutes as no time was taken for insertion of the drains in the preperitoneal space. We observed that the patterns of wound infection in our patients were superficial, deep and intraperitoneal. \{Figure4,5\}

The overall rates of wound infection in both groups were $19 \%$ and $24 \%$ in group A and B respectively. Table 2 showed the distribution of wound infection patterns in both groups within significant distribution.

Table 2. Showing the levels of wound infections in both groups

\begin{tabular}{llll}
\hline & Group A & Group B & P value \\
\hline Superficial & 12 & 13 & \\
Deep & 7 & 10 & $\geq 0.05$ \\
Intraperitoneal & 0 & 2 & \\
Total & $19(19 \%)$ & $25(25 \%)$ & \\
\hline
\end{tabular}

Deep parietal wound infection was treated by intravenous antibiotic injection and ultrasound-guided aspiration or open drainage if US-guided aspiration failed.

The mean time taken in days for managing the deep wound infections was $4.86 \pm 1.57$ days ranging from 3-7days in group A and in group B was 5.2 \pm 1.47 days ranging from 3-7 days.

Intraperitoneal infection was observed in two cases only as localized right iliac fossa and pelvic abscesses in group B treated by reoperation for the1st case and percutaneous aspiration for the pelvic abscess. The time taken for these maneuvers was 7 and 5 days respectively with mean value as $6 \pm 1.4$ days. Therefore the mean total time spent to treat the postoperative wound infection was $4.86 \pm 1.57$ days in group $\mathrm{A}$ and $11.2 \pm 2.87$ days in group $\mathrm{B}\{\mathrm{P} \leq 0.0001, \mathrm{df}=15\}$.

The mean hospital stay for the primary surgical interference in group A was 3.62 \pm 1.49 days and in group B was $3.56 \pm 1.54$ days. Therefore, the mean total hospital stay in both groups was $8.48 \pm 3$ and $14.76 \pm 4.41$ days respectively $\{\mathrm{P} \leq 0.0001$, $\mathrm{df}=198\}$.In the other hand, the mean time to return work after being discharged from the hospital was $8.5 \pm 1.13$ ranged from 7 to 10 days in patients of group A and $8.59 \pm 1.1$ ranged from 7 to10 days in patients of group B. The mean time off from work was calculated as the sum of the mean time of total hospital stay plus the mean time to return work after being discharged. Therefore, the mean time off from work was16.98 \pm 4.13 days in group $\mathrm{A}$ and $23.38 \pm 5.51$ days in group $\mathrm{B}\{\mathrm{P} \leq 0.0001$, $\mathrm{df}=198\}$.

\section{Discussion}

Acute appendicitis is still the commonest abdominal surgical emergency and is known to be the disease of the younger age groups with only $5-10 \%$ of cases occurring in the elderly population $[9,14]$. In agreement with these studies, age of our patients in both groups showed that more than $70 \%$ of them were below the age of 32 years. The mean operative time in previous studies was 60 minutes ranging from 45-75 minutes $[15,16]$ and our data came in concordance with these figures.

Abdominal surgeries have a higher rate of surgical site infections that contributing to increased morbidity and mortality and costs for hospitalization [17]. Increased morbidity and mortality are associated with surgical site infections ranging from wound discharge associated with superficial skin infection to life-threatening conditions such as severe sepsis [18]. The wound classification system categorizes all surgeries into: clean, clean/contaminated, 
contaminated, and dirty, with estimated postoperative rates of surgical site infection being 1\%-5\%,3\%-11\%, 10\%-17\%, and over $27 \%$, respectively [19] and may be as many as $40 \%$ of dirty such as perforated appendicitis [20]. In the present study, our data came parallel to these data where our case presented with complicated appendicitis with reported overall postoperative rates of surgical site infection $19 \%$ and $25 \%$ in both groups. Suction drainage of the preperitoneal space actually seemed to affect postoperative rates of surgical site infection specially the deep and the intraperitoneal subdivisions. Postoperative intra-abdominal abscesses were noted only in patients without drainage of the preperitoneal space with comparable rates as published in literatures $[21,22]$.

The impact of surgical site infection on the extent of hospital stay and time off from work was extensively studied. Many studies reported that surgical site infection can increase hospital stay $[23,24]$. More time was taken for conservative measures using antibiotic injection and wound care [25] or wound drainage whether by open technique or percutaneous maneuvers [26-28]. In our patients, we observed that surgical site infection had direct effect on the extent of hospital stay and time off from work and those with drainage of preperitoneal space showed more time of hospital stay and more time off from work.

\section{Conclusion}

Incidence of surgical site infection is high in case of complicated appendicitis and has its direct effect on the extent of hospital stay and time off from work and those with drainage of preperitoneal space showed more time of hospital stay and more time off from work.

\section{References}

[1] Ballus J, Lopez-Delgado JC, Sabater-Riera J, Perez-Fernandez XL, Betbese AJ, Roncal JA. Surgical site infection in critically ill patients with secondary and tertiary peritonitis: epidemiology, microbiology and influence in outcomes. BMC Infect Dis. 2015 Jul 30;15:304. doi: 10.1186/s12879-015-1050-5.

[2] Sartelli M, Viale P, Koike K, Pea F, Tumietto F, van Goor H, Guercioni G, Nespoli A, Tranà C, Catena F, Ansaloni L, Leppaniemi A, Biffl W, Moore FA, Poggetti R, Pinna AD, Moore EE:WSES consensus conference: Guidelines for first-line management of intra-abdominal infections. World $\mathrm{J}$ EmergSurg 2011, 6:2.

[3] De Ruiter J, Weel J, Manusama E, Kingma WP, van der Voort $\mathrm{PH}$. The epidemiology of intra-abdominal flora in critically ill patients with secondary and tertiary abdominal sepsis. Infection. 2009; 37:522-7.

[4] Augustin P, Kermarrec N, Muller-Serieys C, Lasocki S, Chosidow D, Marmuse JP, Valin N, Desmonts JM, Montravers P: Risk factors for multidrug resistant bacteria and optimization of empirical antibiotic therapy in postoperative peritonitis. Crit Care 2010, 14(1):R20.
[5] Sartelli M, Catena F, Di Saverio S, Ansaloni L, Malangoni M, Moore EE, et al. Current concept of abdominal sepsis: WSES position paper. World J Emerg Surg. 2014 Mar 27. 9 (1):22.

[6] Mazuski JE, Solomkin JS. Intra-abdominal infections. SurgClin North Am. 2009;89(2):421-437.

[7] Rather SA, Bari SU, Malik AA, Khan A. Drainage vs no drainage in secondary peritonitis with sepsis following complicated appendicitis in adults in the modern era of antibiotics. World J Gastrointest Surg. 2013 Nov 27;5(11):300-5.

[8] Petrowsky H, Demartines N, Rousson V, Clavien PA. Evidence-based value of prophylactic drainage in gastrointestinal surgery: a systematic review and meta-analyses. Ann Surg. 2004;240:1074-1084; discussion 1084-1085.

[9] M Vashist. , A Singla, V Malik, M Verma. Abdominal Wall Closure In The Presence Of Sepsis: Role Of Negative Suction. The Internet Journal of Surgery. 2013 Volume 29 Number 1.

[10] Farnell MB, Worthington-Self S, Mucha P Jr, Ilstrup DM, McIlrath DC: Closure of abdominal incisions with subcutaneous catheters. Arch Surg; 1986; 121: 641-48.

[11] Mirilas P, Colborn GL, McClusky DA 3rd, Skandalakis LJ, Skandalakis PN, Skandalakis JE. The history of anatomy and surgery of the preperitoneal space. Arch Surg. 2005 Jan;140(1):90-4.

[12] Motie MR, Ansari M, Nasrollahi HR. Assessment of surgical site infection risk factors at Imam Reza hospital, Mashhad, Iran between 2006 and 2011. Med J Islam Repub Iran. 2014; 28: 52.

[13] Saber A, Ellabban GM, Gad MA and Elsayem K. Open preperitoneal versus anterior approach for recurrent inguinal hernia: a randomized study. BMC Surgery 2012, 12:22 doi:10.1186/1471-2482-12-22.

[14] Omari AH, Khammash MR, Qasaimeh GR, Shammari AK, Yaseen MK, Hammori SK. Acute appendicitis in the elderly: risk factors for perforation. World J Emerg Surg. 2014 Jan 15;9(1):6. doi: 10.1186/1749-7922-9-6.

[15] Katkhouda N,Mason RJ, Towfigh S,A, and Essani R. Laparoscopic Versus Open Appendectomy, A Prospective Randomized Double-Blind Study. Ann Surg. 2005 Sep; 242(3): 439-450.

[16] Stöltzing H1, Thon K. Perforated appendicitis: is laparoscopic operation advisable? Dig Surg. 2000;17(6):610-616.

[17] Aga E, Keinan-Boker L, Eithan A, Mais T, Rabinovich A, Nassar F. Surgical site infections after abdominal surgery: incidence and risk factors. A prospective cohort study. Infect Dis (Lond). 2015 Nov;47(11):765-71.

[18] Korol E, Johnston K,Waser N,Sifakis F, Jafri HS, Lo M, and Kyaw MH. A Systematic Review of Risk Factors Associated with Surgical Site Infections among Surgical Patients PLoS One. 2013; 8(12): e83743.

[19] Ortega G, Rhee DS, Papandria DJ, Yang J, Ibrahim AM, Shore AD, Makary MA, Abdullah F. An evaluation of surgical site infections by wound classification system using the ACS-NSQIP. J Surg Res. 2012 May 1;174(1):33-8.

[20] ReichmanDE, and James A Greenberg JA. Reducing Surgical Site Infections: A Review. Rev Obstet Gynecol. 2009 Fall; 2(4): 212-221. 
[21] Wei HB, Huang JL, Zheng ZH, Wei B, Zheng F, Qiu WS, Guo WP, Chen TF, Wang TB. Laparoscopic versus open appendectomy: a prospective randomized comparison. Surg Endosc. 2010 Feb;24(2):266-9.

[22] Krisher SL, Browne A, Dibbins A, Tkacz N, Curci M. Intra-abdominal abscess after laparoscopic appendectomy for perforated appendicitis. Arch Surg. 2001 Apr;136(4):438-41.

[23] Cheng Y, Zhou S, Zhou R, Lu J, Wu S, Xiong X, Ye H, Lin Y, $\mathrm{Wu} \mathrm{T}$, Cheng $\mathrm{N}$. Abdominal drainage to prevent intra-peritoneal abscess after open appendectomy for complicated appendicitis. Cochrane Database Syst Rev. 2015 Feb 7; 2:CD010168. Epub 2015 Feb 7.

[24] Ballus J, Lopez-Delgado JC, Sabater-Riera J, Perez-Fernandez XL, Betbese AJ, Roncal JA. Surgical site infection in critically ill patients with secondary and tertiary peritonitis: epidemiology, microbiology and influence in outcomes. BMC Infect Dis. 2015 Jul 30;15:304. doi: 10.1186/s12879-015-1050-5.

[25] Meagher H,Clarke Moloney M, Grace PA. Conservative management of mesh-site infection in hernia repair surgery: a case series. Hernia, 2015,19(2): 231-237

[26] Yau KK, Siu WT, Tang CN, Yang GP, Li MK. Laparoscopic versus open appendectomy for complicated appendicitis. J Am Coll Surg. 2007 ;205(1):60-5.

[27] Iqbal CW, Knott EM, Mortellaro VE, Fitzgerald KM, Sharp SW, St Peter SD..Interval appendectomy after perforated appendicitis: what are the operative risks and luminal patency rates? J Surg Res. 2012 Sep;177(1):127-30.

[28] Gupta R, Sample C, Bamehriz F, Birch DW. Infectious complications following laparoscopic appendectomy. Can J Surg. 2006 Dec;49(6):397-400. 